\title{
Mejora de la eficiencia energética de la producción de ladrillos de cerámica roja a partir del empleo como biocombustible de material lignocelulósico densificado Improving energy efficiency on production of clay ceramic bricks
using lignocellulosic-densified-material based biofuel
}

\author{
Iván Machado L.*1, José F. Martirena H.*, Idalberto Herrera M.*, Sergio Quiroz**, Maria Jesus Lamela R.**, Raúl Gonzalez L.* \\ * Universidad Central "Marta Abreu" de las Villas. CUBA \\ ** Escuela Politécnica Superior de Ingeniería de Gijón (EPSIG) Gijón. ESPAÑA
}

\begin{abstract}
Fecha de recepción: $27 / 04 / 2011$ Fecha de aceptación: $27 / 06 / 2011$

Resumen PAG. 208 - 223

En el presente trabajo se exponen algunas experiencias en el propósito de obtener materiales de construcción como los ladrillos rojos cocidos a partir de una fuente energética alternativa proveniente de sustituir la madera o leña por residuos de material lignocelulósico sometidos al proceso de densificación con baja presión. El proceso de densificación con baja presión implica el empleo de algún tipo de aglomerante para lo cual en este trabajo se propone el uso del material arcilloso. Sobre esta base el objetivo principal de este estudio es evaluar el efecto que se produce en el consumo específico del biocombustible durante la fabricación artesanal de ladrillos al sustituir parcialmente la leña por la biomasa densificada. Se expone la relación entre algunas propiedades del biocombustible que permiten aumentar la relación ladrillos / kilogramo de combustible desde 1.1 a 1.4 lo que mejora la eficiencia del proceso de fabricación de ladrillos disminuyendo el consumo especifico con respecto al uso del combustible tradicional con la consiguiente mejora ambiental del proceso.
\end{abstract}

Palabras Clave: Ecomateriales, ladrillos, biomasa, densificación

Abstract

This work presents some experiences in producing building materials, such as clay bricks, from an alternative energy source that replaces wood or firewood by waste lignocellulosic material submited to the process of densification under low pressure. The densification process at low pressure involves the use of a binder; this paper proposes the use of clay material as binder. The main objective of this study was to evaluate the effect in the consumption of biofuel during the production of handmade bricks, partially replacing wood by densified biomass. Some properties of the biofuel are identified to increase the bricks-to-fuel consumption ratio from 1.1 to 1.4. This improves the efficiency of the production process, reduces specific consumption regarding the use of traditional fuels with its consequent environmental improvement of the process.

Keywords: Eco-materials, bricks, biomass, densification

\section{Introducción}

El aprovechamiento de residuos de procesos agroindustriales constituye en la actualidad una significativa fuente de energía para muchos países del Tercer Mundo, no obstante aun no se alcanza un adecuado y sistemático uso de ellos como fuente de energía alternativa para la producción de diversos materiales de construcción.

\section{Introduction}

The use of agro-industrial process waste currently constitutes a significant source of energy for many Third World countries, however it has not yet reached a proper and consistent use of them as a source of alternative energy for the production of various building materials.

\footnotetext{
1 Autor de correspondencia / Corresponding author:

E-mail: ivanm@uclv.edu.cu
} 
La densificación de residuos proveniente de diversas fuentes de biomasa, es una opción atractiva para valorizar y mejorar las propiedades de tales desechos, puesto que disminuyen los costos de su manejo, transporte, almacenaje, etc., e incrementa su poder calorífico volumétrico. (Jamradloedluk, 2005).

El Centro de Investigaciones y Desarrollo de las Estructuras y los Materiales de Construcción (CIDEM), en colaboración con dos centros de investigación acreditados, se ocupa desde hace un lustro del proceso de reciclaje y densificación de residuos de madera. Para ello se aplican bajas presiones de compactación (de hasta 5 mega pascales, MPa) y el empleo de un material arcilloso como aglomerante, logrando un producto sólido aglomerado que en adelante se denominara bloque sólido combustible (BSC) o más comúnmente briquetas, de evidente interés para su aplicación en la pequeña industria de los materiales de construcción, (Martirena 2003, González, 2003).

El material arcilloso constituye un viable y económico aglomerante en un entorno local de la cerámica artesanal, sin embargo es necesario esclarecer los efectos que genera en las propiedades físico-mecánicas y físico -químicas del sólido biocombustible y su incidencia para la obtención del ladrillo rojo cocido. El trabajo presenta los resultados de investigaciones y evaluaciones de la producción de ladrillos en un horno típico situado en Manicaragua, provincia de Villa Clara, Cuba y la aplicación de una metodología para implementar la sustitución parcial de leños de madera por el material conglomerado arcilla biomasa disminuyendo el consumo total de combustible sin afectar de forma significativa los parámetros físicos y mecánicos de los ladrillos.

La producción anual de ladrillos del municipio Manicaragua alcanza las $\mathbf{2 8 0}$ mil unidades / año, la creciente actividad de productores individuales de ladrillos en la municipalidad implica un serio proceso de deforestación, que podría causar la destrucción de cerca de $\mathbf{1 1 . 5}$ ha de bosques anualmente.

Según Curbelo, 2002, el volumen de residuos de madera aserrada en Cuba asciende a $70.000 \mathrm{~m}^{3}$ anuales, estos residuos son utilizados de forma irregular por la industria avícola y porcina, sin embargo en ocasiones no tienen una aplicación concreta provocando una innecesaria ocupación y contaminación de áreas productivas donde muchas veces son incinerados sin dar al calor generado un empleo racional.
Densification of waste from various sources of biomass is an attractive option for enhancing and improving the properties of such wastes, as may be their lower costs for handling, transportation, storage, etc. and it increases its calorific volume. (Jamradloedluk, 2005).

The Center for Research and Development of Structures and Construction Materials (CIDEM in Spanish), in collaboration with two other certified research centers, deals for the last five years with the recycling process and densification of wood residues. This is done by using low compaction pressures (up to 5 mega Pascals, MPa) and the use of particular clay material as binder, obtaining a solid agglomerated hereinafter called solid fuel block (BSC in Spanish) or more commonly briquettes, of obvious interest for their application in small industry of building materials (Martirena 2003, Gonzalez 2003).

The clay material is a viable and cheap binder in local ceramics environment, however it is necessary to clarify the effects generated in the physical-mechanical properties and physical-chemical ones of solid biofuel and its impact on the obtantion of fired red brick.

The paper presents the results of research and evaluation of the production of bricks in a typical kiln located in Manicaragua, province of Villa Clara, Cuba and the application of a methodology to implement partial replacement of logs of wood for clay conglomerate material - biomass reducing overall fuel consumption significantly without affecting the physical and mechanical parameters of the bricks.

Manicaragua municipality annual production of bricks reaches $\mathbf{2 8 0} 000$ units / year. Increasingly activity of individual producers of bricks in the zone involves a serious deforestation process, which could cause annually the destruction of about $\mathbf{1 1 . 5}$ ha of forest.

According to Curbelo, 2002, the annual volume of waste lumber in Cuba reaches 70,000 cubic meters. These wastes are used by poultry and swine industries, but sometimes do not have a specific occupation and cause unnecessary pollution in productive areas which are often burned without giving to the generated heat a rational use. 
Estudios previos para determinar la disponibilidad de residuos provenientes del tratamiento de la madera en Villa Clara, identifica como fuente mayoritaria los aserríos con más del $75 \%$ del aserrín producido en la región, aportando talleres y carpinterías locales el resto como muestra la Figura I. (González, 2004).

Los aserríos evaluados generan cada año alrededor de $280 \mathrm{~m}^{3}$ de residuos en forma de aserrín, con un valor energético de $378 \mathrm{GJ} / a n ̃ o$, lo cual podría constituir un significativo potencial energético para la producción de cerámica roja u otras aplicaciones en el campo de las industrias de materiales de construcción locales.

Una etapa muy importante en la producción del ladrillo ocurre durante la quema en el horno, a ella se asocia casi la totalidad del consumo de energía, existiendo una relación directa entre el régimen térmico empleado y las propiedades deseadas del ladrillo de barro cocido. El régimen térmico depende del nivel de operación del horno y de las características del combustible empleado, garantizando el perfil de temperaturas requerido en el horno para lograr la apropiada transformación del material arcilloso y obtener un producto final que cumpla las especificaciones de calidad.

El aumento de la demanda actual de madera empleada en las producciones de cerámica roja en varios países en desarrollo ha conducido al gradual incremento de la deforestación (Betancourt, 2007), por lo que densificar residuos de biomasa podría resultar una atractiva opción para facilitar su empleo como biocombustible en la fabricación de ladrillos y otros productos cerámicos.
Previous studies were done to determine the availability of residues from wood treatment in Villa Clara. They identify as largest source the sawmills that produce over $75 \%$ of the sawdust produced in the region, providing it to local carpentry workshops and the rest as shown in Figure I. (Gonzalez, 2004).

The sawmills annually evaluated generate about $280 \mathrm{~m}^{3}$ of waste in the form of sawdust, with an energy value of $378 \mathrm{G}$ / / year, which could be a significant energy potential for production of red ceramic or other applications in industries of local building materials.

A very important stage in bricks production occurs during the burning process in the oven. Almost all the energy is used there, existing a direct relationship between the thermal regime used and the desired properties of clay brick. Thermal regime depends on the level of operation of the oven and the characteristics of the fuel used, ensuring the required temperature profile in the furnace to achieve proper transformation of the clay material and a final product that meets quality specifications.

Increased current demand for wood used in the production of red ceramics in several developing countries has led to a gradual increase in deforestation (Betancourt, 2007), that is why to densify waste biomass could be an attractive option in order to facilitate the use of it as biofuel, in the manufacture of bricks and other ceramic products.

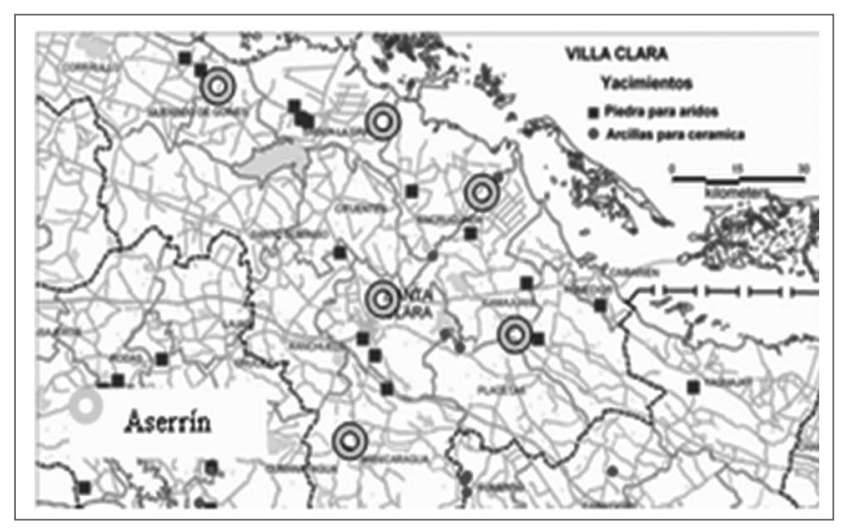

Figura 1. Locaciones de aserrín y afloramientos de arcilla en Villa Clara, Cuba. Fuente: Machado 2002; Mapas de micro minería Figure 1. Clay and sawdust sources in Villa Clara, Cuba. Source: Machado 2002; Maps in micro mining 
En general los residuos primarios y secundarios del procesamiento de madera, del bagazo, paja de caña, de trigo, maíz, arroz y otros desechos, se caracterizan por su poca densidad y bajo poder calórico por unidad de volumen por lo que resultan inadecuaos para su combustión directa. (Bhattacharya, 2002).

Una importante característica del sólido combustible es su densidad, diferentes reportes evalúan la densidad relajada de las briquetas fabricadas con baja presión de compactación entre $200 \mathrm{Kg}$. / $/ \mathrm{m}^{3}$ $700 \mathrm{Kg}$. /m³ (Jamradloedluk, 2005; Faxälv, 2007). Teniendo en cuenta la amplitud de límites que adopta la densidad en función de diversos factores se acepta, en el marco de este trabajo, $450 \mathrm{Kg} . / \mathrm{m}^{3}$ como valor mínimo para briquetas densificadas según el proceso tecnológico propuesto.

\section{Materiales y métodos}

Los residuos generados en los aserraderos estudiados poseen una similar distribución del tamaño de partículas, donde el aserrín colectado aleatoriamente muestra que la mayor fracción de partículas está por debajo de los 2.5 milímetros en más del $\mathbf{8 5} \%$ del material analizado, no obstante durante el acondicionamiento del material suelto para la elaboración de las muestras se realiza el tamizado del material excluyendo solo las partículas mayores a los $5 \mathrm{~mm}$, para facilitar un superior aprovechamiento de los residuos disponibles el material retenido se tritura en un molino de martillo y se tamiza por la abertura fijada al efecto.

El análisis químico de las materias primas para la obtención del aglomerado arroja la no existencia de trazas de metales pesados u otros elementos que podrán ser perjudiciales al ambiente durante el proceso de combustión de la biomasa.

El material arcilloso se obtiene de diferentes fuentes garantizando diversidad de propiedades, lo cual permite evaluar su efecto sobre la estabilidad del conglomerado que se obtiene al ser mezclado con la biomasa y sometido a baja presión.

El material arcilloso es diluido en agua $y$ mezclado con biomasa en diferentes proporciones (1090, 20-80, 30-70). Luego mediante una prensa universal para ensayos mecánicos ZD-40 con capacidad de hasta $500 \mathrm{KN}$ se compacta en un molde metálico cilíndrico de longitud y diámetro igual a $\mathbf{1 5 0}$ milímetros logrando además una abertura longitudinal en el centro del bloque de $25 \mathrm{~mm}$ de diámetro.
In general, primary and secondary waste processing wood, bagasse, cane straw, wheat, corn, rice and other wastes straw, are characterized by their low density and low calorific value per unit volume so they are inadecuated for direct combustion. (Bhattacharya, 2002).

An important feature of the solid fuel is its density. Different reports evaluate relaxed density of briquettes made with a low compaction pressure of $200 \mathrm{~kg} / \mathrm{m}^{3}$ 700 kg / m³ (Jamradloedluk, 2005; Faxälv, 2007). Given the extent of limits adopted by density in front of several factors, it is accepted as part of this work, $450 \mathrm{~kg} / \mathrm{m}^{3}$ as densified briquettes minimum value for the technological proposed process.

\section{Materials and methods}

Waste generated at the mills of this research have a similar particle size distribution, where the sawdust collected randomly shows that the largest fraction of particles is below $2.5 \mathrm{~mm}$ in $\mathbf{8 5} \%$ of the analyzed material, however during the management of loose material for the preparation of samples, the screening of material is performed excluding only particles larger than $5 \mathrm{~mm}$. In order to facilitate a greater use of available waste retained material, it is crushed in a hammer mill and sieved through the opening set for that purpose.

Chemical analysis of raw materials for agglomerate obtaintion shows the absence of heavy metals traces or other elements which may be environmental harmful during biomass combustion process.

Clay material is obtained from different sources to ensure diversity of properties, allowing to assess its effect on the stability of the mixture obtained when biomass is added and subjected to low pressure.

Clay material is diluted in water and mixed with biomass in different proportions (10-90, 20-80, 30-70). Then using a universal mechanical testing press ZD-40 with capacity of $500 \mathrm{KN}$ it is compacted in a cylindrical metal mold of length and diameter of $150 \mathrm{~mm}$, also achieving a longitudinal opening in the center block 25 $\mathrm{mm}$ in diameter. 
La densidad de las briquetas se calcula a partir de mediciones promedio de sus dimensiones y peso empleando Pie de Rey y balanza digital de precisión 0.001gramos. En el análisis de la densidad de las briquetas o bloques sólidos se utilizan las recomendaciones de la norma ASAE S269.4.

La razón de densidad (RD) tiene una relación inversa con respecto a la densidad y permite evaluar la estabilidad del proceso de compresión - relajación del material aglomerado, se obtiene a partir de la medición de la variación de las dimensiones de la briqueta y del peso como resultado de la pérdida de humedad.

Se establece a través de métodos de análisis de asociación entre variables las relaciones funcionales de algunos parámetros involucrados en el proceso de densificación, mientras el cálculo del calor especifico de combustión (CEC), se realiza acorde al por ciento constitutivo de los elementos químicos obtenidos mediante el análisis elemental e inmediato, caracterizando las muestras en términos del contenido de humedad, volátiles, carbono fijo y cenizas, al aplicar la ecuación de Dulong - Berthelot (Cukierman 1996).

Para el análisis del tiempo de combustión ó razón de combustión (BR) de las briquetas fabricadas de aserrín con baja presión y la arcilla como aglomérate se realza un diseño de experimento factorial fraccionado (DFF) donde la humedad posee una significativa influencia sobre el calor especifico de combustión, además se valora el contenido de aglomerante pues según Chin, (2000) este factor puede modificar con alto grado de incidencia las propiedades del combustible.

Para determinar el tiempo de combustión se instrumenta con un analizador de gases de combustión tipo RBR - ECOM - SG PLUS un combustor de baja temperatura (cocina eficiente), donde se introducen las briquetas y se comprueba el tiempo de inflamación de los compuestos volátiles que emiten una Ilama azul resplandeciente alrededor de la briqueta y desde el orificio central, se confirma la evolución del proceso a través del analizador de gases considerando concluida la combustión cuando el sólido remanente no emite el brillo rojo característico del material ardiente e invariablemente comienza a disminuir bruscamente la temperatura del flujo de gases.

Por otro lado se toman de forma aleatoria tres briquetas por tratamiento según el diseño realizado, se colocan en una mufla tipo LH 30/14, marca Nabertherm a 500 OC durante 2 minutos para lograr la oxidación del sólido biocombustible, y una vez evaluada la diferencia de pesos, se determina el rendimiento de la combustión.
Density of briquettes is calculated from average measurements of their size and weight, using caliper and precision digital balance $\mathbf{0 . 0 0 1}$ grs. In the density analysis of briquettes or solid blocks are used the recommendations of the ASAE S269.4. Standard.

Density ratio (DR) has an inverse relationship with respect to density and can assess the stability of the compression process - relaxation of the agglomerated material is obtained from measurements of the variation in the dimensions of briquette and its weight as a result of moisture loss.

Is established through methods of analysis of association among functional variables of some parameters involved in the densification process, while calculating the specific combustion heat (CEC in Spanish) was done according to the percent constituent of chemical elements obtained by elemental and immediate analysis, characterizing samples in terms of moisture, volatiles, fixed carbon and ash, applying Dulong - Berthelot equation (Cukierman 1996).

For the analysis of the burning time or burning ratio (BR) of briquettes made of sawdust at low pressure and clay as aglomerate, a fractional experimental design is produced (DFF in Spanish) where moisture has a significant influence on the specific heat combustion. Also assesses the binder content since, according to Chin (2000), this factor can be modified with high incidence on fuel properties.

To determine the burning time it is implemented a low-temperature combustor (efficient kitchen) with a flue gas analyzer RBR type - ECOM - SG PLUS. The briquettes are entered and the time of ignition of volatile compounds checked, which emit a bright blue flame around the briquette and from the center hole. The evolution of the process is confirmed through the gas analyzer once firing is considered completed and when the remaining solid combustion does not emit the characteristic red glow of burning material and temperature of gas flow invariably begins to sharply decrease.

On the other hand are taken at random three briquettes according to designed treatment. They are placed in a muffle type LH 30/14, Nabertherm, to 500 C for 2 minutes in order to achieve oxidation of solid biofuel, and after assessing the weights difference, combustion efficiency is determine. 
La eficiencia energética del biocombustible se relaciona con la oxidación completa y el aprovechamiento del calor generado, por tanto su incremento se asocia a la disminución de las pérdidas, para con ello restringir el índice de consumo especifico y posibilitar una consecuente mejora ambiental del proceso. Como procedimiento de estimación de la eficiencia de la producción de ladrillos de cerámica roja se realizan diferentes quemas sucesivas, donde se sustituye parcialmente la leña por el BSC, verificando el consumo específico del biocombustible densificado, la variación de temperatura y como resultado las propiedades físicomecánicas del ladrillo cerámico.

\section{Desarrollo}

Densidad relajada (DR) y Relación de densidad (RD) La densidad final de las briquetas depende de diversos factores entre ellos la relación entre la magnitud de la presión de compresión y el distensionamiento ó relajamiento del material, las propiedades físicas iniciales del material lignocelulósico y las características del proceso de aglomeración (presión, tiempo, naturaleza y contenido porcentual del aglomerante, etc.).

Al estimar los parámetros del modelo funcional que relacionan la densidad relajada con los factores: presión (1-5 MPa), humedad (cantidad de agua 1-2.5 L / Kg. de biomasa), tiempo de prensado ( 15 - 60 segundos) contenido de aglomerante (10 - 30 por ciento) y actividad del aglomerante arcilloso, definida esta última por la relación entre la plasticidad y el contenido de arcilla, se valora el nivel de significación y la simplificación del modelo al extraer del análisis los factores menos explicativos.

El diseño de experimento fraccionado (DFF= $\left.2^{(5-1)}\right)$, realizado teniendo en cuenta el contenido de aglomerante (CA) a partir del material arcilloso de alta actividad procedente del municipio Manicaragua determina un valor promedio de $596 \mathrm{Kg} . / \mathrm{m}^{3}$ de la densidad relajada para los tratamientos muestrales definidos por la relación entre los factores y niveles involucrados.

La relación de densidad esta definida según Chin, 2000 como ((DH-DR)/ DH), donde DH es la densidad inicial ó húmeda y DR es la densidad final ó relajada.
Biofuel energy efficiency is related to the complete oxidation and use of heat, so the increase is associated with a decrease in losses, thereby restricting the rate of specific consumption and enabling a consistent environmental improvement process. As a method for efficiency estimation of production of red ceramic bricks, different successive fires are made, which partially replace the wood by the BSC, verifying the specific consumption of densified biofuels, variations in temperature and, as a result, physical mechanical properties of ceramic brick.

\section{Development}

Relaxed density (RD) and density ratio (DR) Final density of briquettes depends on several factors including the relationship between the magnitude of compression pressure and stretching or relaxation of material, the initial physical properties of the lignocellulosic material and characteristics of the agglomeration process (pressure, time, nature and percentage of binder content, etc.).

Upon estimating the functional model parameters that relate the relaxed density with the following factors: pressure (1-5 MPa), moisture (water quantity 1-2.5 L / biomass kg), pressing time (15 - 60 seconds) contained binder (10 - 30 percent) and activity of the clay binder, the latter defined by the relationship between plasticity and clay content, assesses the significance level and simplification of model taking from the analysis the less explanatory factors.

The split design of experiments (DFF= 2(5-1)), carried out taking into account the binder content (CA) from the high-activity clay material from Manicaragua municipality determines an average of $596 \mathrm{~kg} / \mathrm{m}^{3}$ relaxed density for sample treatments defined by the relationship between factors and levels involved.

Density ratio is defined by Chin, 2000 as ( $(\mathrm{DH}-$ DR) / DH), where DH is the initial density or the wet one and DR is the final density or the relaxed one. 
La Figura 2, grafica la curva de valor porcentual de la relación de densidad versus presión aplicada al variar la actividad del material arcilloso, asumiendo igual contenido de aglomerante $(20 \%)$ y humedad $(H=1.7$ litros de agua / Kg. de aserrín), mezclando biomasa con diferentes materiales arcillosos con propiedades físicas y estructurales que determinan sus valores de actividad (alta. media y baja).

Se confirma la disminución del relajamiento con el aumento de la presión de compactación, así como la tendencia a disminuir la RD en función del aumento de la actividad del aglomerante.

Los valores hallados para la relación de densidad presentan un recorrido de 17 a $45 \%$, los resultados del ajuste a un modelo de regresión lineal múltiple describe la relación entre $R D$ y 3 variables independientes con una relación inversa con los factores controlados. La ecuación del modelo ajustado adopta la forma siguiente:
Figure 2 plots the curve of percentage value of the density ratio versus pressure applied upon varying the activity of the clay material, assuming the same binder content $(20 \%)$ and humidity ( $H=1.7$ water liters / sawdust $\mathrm{kg}$ ) by mixing biomass with different clay materials with structural and physical properties that determine their activity values (high, medium and low).

This confirms the decrease of relaxation with increasing compaction pressure and the tendency to decrease the RD according to the increased activity of the binder.

The values found for the relationship of density go from 17 to $45 \%$, the results correspond to a multiple linear regression model that describes the relationship between RD and 3 independent variables with an inverse relation with the controlled factors. The equation of the model takes the following form:
Dado que el p-valor en la tabla ANOVA es inferior a 0.01, existe relación estadísticamente significativa entre las variables para un nivel de confianza del $99 \%$. El estadístico R-cuadrado indica que el modelo explica un $87 \%$ de la variabilidad en RD, donde RD es la relación de densidad en por ciento, $\mathrm{P}$ la presión aplicada en MPa; mientras CA es el contenido de aglomerante arcilloso y AA el grado o nivel de actividad del aglomerante.

\section{Calor específico de combustión (CEC)}

Para determinar la influencia de los parametros de fabricación del sólido densificado sobre el valor del CEC se emplea el análisis de regresión múltiple, considerando los factores ó variables que intervienen en el proceso.
Since the p-value in the ANOVA table is less than 0.01 , statistically significant relationship exists between the variables for a confidence level of a $99 \%$. R-square statistic indicates that the model explains $87 \%$ of the variability in $\mathrm{RD}$, where $\mathrm{RD}$ is the density ratio in percentage, $P$ the applied pressure in $\mathrm{MPa}$, while $\mathrm{CA}$ is the content of clay binder and AA the degree or activity level of the binder.

Specific Heat of combustion (CEC in Spanish) In order to determine the influence of manufacturing parameters of densified solid on the value of CEC multiple regression analysis is used, considering factors or variables involved in the process.

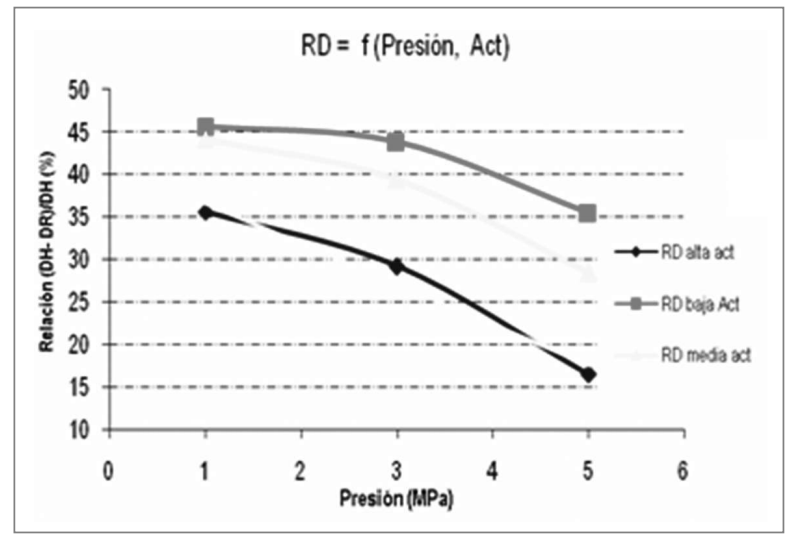

Figura 2. Valor porcentual de la RD en función de la presión aplicada y la actividad del aglomerante

Figure 2. RD percentage value as a function of applied pressure and binding agent activity 
Las briquetas de baja densidad muestran dependencia entre el CEC del material y el proceso tecnológico de fabricación. Faxälv (2007) ha reportado como briquetas de aserrín y papel alcanzan un CEC entre $16.2-18.1 \mathrm{MJ} / \mathrm{kg}$ en función del contenido de aglomerante y el proceso tecnológico. Según González (2003), en briquetas de paja de caña se logra un poder calórico de 17.87 MJ/Kg., sin embargo, Martirena, (1999), reporta $15 \mathrm{MJ} / \mathrm{Kg}$. mediante análisis térmicos, lo que al parecer tiene en cuenta el nivel de afectación que produce la adición del aglomerante inorgánico.

Dado el resultado promedio del cálculo del calor específico de combustión, es posible determinar la relación del mismo con los factores involucrados. El análisis del ajuste a un modelo de regresión lineal múltiple viene dado por el diseño de experimento considerando los factores: humedad, presión, tiempo de compresión (dwell time) de la biomasa en el dado y contenido de aglomerante (CA) en los niveles alto y bajo. Los resultados del modelo describe la relación entre CEC y 2 variables independientes en las condiciones de la aplicación de baja presión y la adición del aglomerante arcilloso. La ecuación del modelo ajustado toma la forma siguiente:
Low-density briquettes show dependency between CEC of the material and manufacturing process technology. Faxälv (2007) has confirm how sawdust and paper briquettes reach a CEC between 16.2 - 18.1 MJ / $\mathrm{kg}$ depending on the binder content and the technological process. According to González (2003) sugarcane straw briquettes achieve a caloric power of $17.87 \mathrm{MJ} / \mathrm{kg}$. However, Martirena (1999), reported 15 MJ / kg. by thermal analysis, which apparently takes into account the level of impact caused by the addition of inorganic binder.

Since the average result of calculations of the specific heat of combustion, it is possible to determine the relationship of the same factors involved. The analysis of adjusting to a multiple linear regression model is given by the experiment design considering the following factors: humidity, pressure, compression time (dwell time) of biomass and binder content (CA) in high and low levels.

The results of the model describes the relationship between CEC and 2 independent variables in the conditions of application of low pressure and the addition of clay binder. The equation of the fitted model takes the following form:

$\mathrm{CEC}=17,25-1,09 * \mathrm{H}-0,366^{*} \mathrm{CA}$

Dado que el p-valor en la tabla ANOVA es inferior a 0.01, existe relación estadísticamente significativa entre las variables para un nivel de confianza del $99 \%$. El estadístico R-cuadrado indica que el modelo explica el $91 \%$ de la variabilidad en [2] donde: CEC es el calor especifico de combustión, expresado en MJ/Kg., H es humedad expresada en litros de agua $\mathrm{L} / \mathrm{Kg}$. de aserrín y CA el contenido de aglomerante.

Se manifiesta una relación inversa entre el calor específico de combustión, la humedad y el contenido de aglomerante. La relación del poder calórico de densificados de biomasa y la humedad ha sido suficientemente abordado por la comunidad científica confirmando estos resultados los expuestos por Bhattacharya, (2002) y otros investigadores, al parecer el aumento del contenido de aglomerante produce en este caso un efecto equivalente al de la humedad.
Since the $p$-value in the ANOVA table is less than 0.01 , statistically significant relationship exists between the variables for a confidence level of $99 \%$. Rsquare statistic indicates that the model explains $91 \%$ of the variability in [2] where CEC is the specific heat of combustion, expressed in $\mathrm{MJ} / \mathrm{Kg}$., $\mathrm{H}$ is moisture in liters of water $\mathrm{L}$ / sawdust $\mathrm{kg}$. and CA is the binder content.

An inverse relationship is manifested between the specific heat of combustion, moisture and binder content. The ratio of the calorific value of densified biomass and moisture has been sufficiently addressed by the scientific community to confirm these results, as presented by Bhattacharya (2002) and others, apparently increasing the binder content produces in this case an effect equivalent to moisture. 
El análisis estadístico rebela que la presión no resulta un factor estadísticamente significativo para un nivel de confianza del $90 \%$ ó más No obstante su bajo nivel de significación podría considerarse que el aumento de la presión tiene relación directa con el CEC, lo cual puede estar asociado con el aumento de la densidad y probablemente con el contenido porcentual de carbono fijo en el volumen del bloque, lo cual a su vez produce un incremento del poder calórico volumétrico, atendiendo al valor promedio de la densidad y del CEC puede representar $10590 \mathrm{MJ} / \mathrm{m}^{3}$

\section{Razón de combustión (BR)}

La razón de combustión (burning rates), caracteriza la velocidad a la que suceden los diferentes fenómenos relacionados con el proceso de oxidación del material lignocelulósico. Chin (2000) y Cristofer, 2006) plantean la importancia de su determinación al estar relacionada con las consideraciones necesarias del diseño de sistemas de combustión

La Figura 3 muestra el resultado del ensayo, donde se aprecia el valor de la razón de combustión en $\mathrm{g} / \mathrm{min}$. contra la densidad de cada tratamiento organizado según la matriz del diseño de experimento. Los resultados demuestran la tendencia de la razón de combustión al tomar valores de 95 a $128 \mathrm{~g} / \mathrm{cm}$., en relación inversa a la densidad de la briqueta, evidenciando como el contenido de aglomerante puede retardar el proceso de oxidación del material lignocelulósico al disminuir la interacción de este con el oxigeno.
Statistical analysis reveals that the pressure is not a statistically significant factor for a confidence level of $90 \%$ or more. Despite its low level of significance could be seen as increasing pressure is directly related to the CEC, which can be associated with increased density and probably the percentage of fixed carbon content in the block volume, which in its turn produces an increase in caloric volume, taking the average value of density and CEC may represent $10590 \mathrm{MJ} / \mathrm{m}^{3}$

\section{Combustion ratio (BR)}

The burning ratio (burning rates), characterizes the rate at which the different phenomena occurr related to the oxidation process of lignocellulosic material. Chin (2000) and Cristofer (2006), discuss the importance of its determination since it is related to the necessary considerations for the design of combustion systems.

Figure 3 shows the test result, where it can be seen the value of the ratio of combustion in $\mathrm{g} / \mathrm{min}$. In front of density of each treatment arranged according to the experimental design matrix.

The results show the tendency of the rate of combustion taking values from 95 to $128 \mathrm{~g} / \mathrm{cm}$., in an inverse proportion to the density of briquette, showing how the binder content may slow down the oxidation process of lignocellulosic material by decreasing its interaction with oxygen.

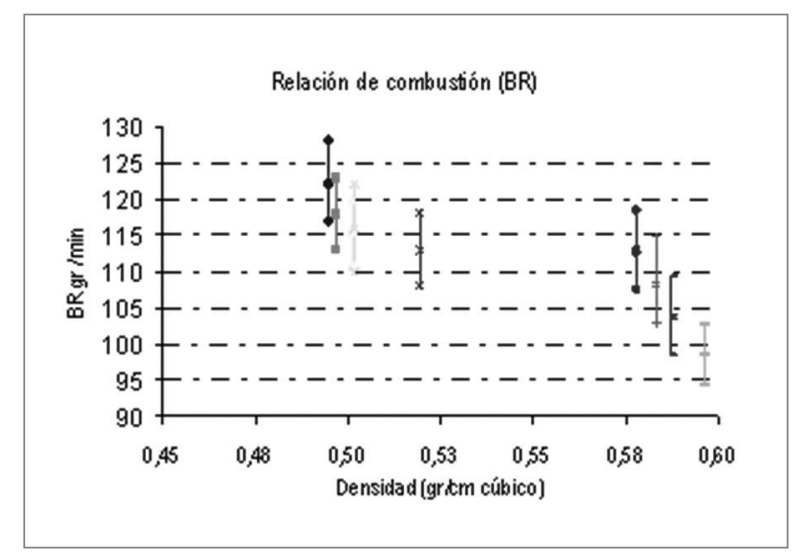

Figura 3. Razón de combustión en función de la densidad y la actividad

Figure 3. Combustion ratio as a function of density and activity 
Estos resultados son consistentes con la teoría, según Christofer, (2006) la variable densidad puede incidir sobre la velocidad de combustión al limitar los procesos de difusión e interacción del material oxidante. Chin, 2002, por su parte plantea como el tiempo de combustión de briquetas se incrementa de forma proporcional al contenido de aglomerante y al tiempo de prensado, en opinión del autor puede estar relacionado con el aumento de la densidad y la probable disminución de la interacción con el oxigeno, llegando a confirmar los resultados expuestos.

\section{Rendimiento del biocombustible}

El rendimiento del combustible, expresa la calidad del portador energético y el proceso de combustión, por lo que puede ser definido como la relación entre el peso total de la muestra o espécimen y el peso del material potencialmente combustible, expresado en por ciento. (Assureira, 2002)

Este parámetro compara la ventaja relativa de ocurrencia de la combustión de las briquetas fabricadas en condiciones específicas, de modo que se determina qué condiciones de fabricación y obtención facilitan la combustión de unas con respecto a otras, a partir de la adaptación de expresiones expuestas en la literatura se propone la siguiente expresión de cálculo:
These results are consistent with the theory, according Christofer, (2006), the variable of density can influence the burning rate by limiting the diffusion processes and interaction of the oxidizing material. Chin, 2002, states that briquettes burn time increases in proportion to the binder content and to pressing time. In the opinion of the author it may be associated with increased density and possible reduced interaction with oxygen, confirming the results presented.

\section{Performance of biofuel}

Fuel efficiency expresses the quality of energy carrier and the process of combustion, which can be defined as the ratio of total weight of sample and the weight of potentially combustible material, expressed in percent. (Assureira, 2002).

This parameter compares relative advantage of occurrence of combustion of briquettes produced under specific conditions, determining which conditions of manufacture and obtention facilitate combustion with respect to each other. From adaptation of several literature expressions, the following calculation can be proposed:

$$
\eta=\left[\left(P_{\text {Total }}-P_{\text {Residuo }}\right) / P_{\text {Combustible }}\right] * 100
$$

Donde: $\eta=$ Rendimiento; $P_{\text {Tot }}=$ Peso total de la briqueta; $\mathrm{P}_{\text {Res }}=$ Peso del residuo;

$\mathrm{P}_{\mathrm{Cb}}=$ Peso del material potencialmente combustible $\mathrm{P}_{\mathrm{Cb}}=\left(\mathrm{P}_{\text {Biomasa }}-(1-\%\right.$ Ceniza $\left.)\right)+\left(\mathrm{P}_{\text {aglom }} * \mathrm{PPI} / 100\right)$

Mediante el método de regresión lineal múltiple se evalúa el nivel de significación de los factores implicados, el factor tiempo no resulta significativo para un nivel de significación del $95 \%$. Los resultados del ajuste a un modelo de regresión lineal múltiple revela el promedio del rendimiento de la combustión del material aglomerado aserrín + arcilla a partir de la descripción de la relación entre el rendimiento y 3 variables independientes; La ecuación del modelo ajustado es: where: $\eta=$ performance; $P_{T o}=$ Total briquette weight; $P_{\text {Res }}=$ Weight residue;

$P_{C b}=$ Potentially combustible material weight; $P_{C b}=\left(P_{\text {Biomasa }}-(1-\%\right.$ Ashes $\left.)\right)+\left(P_{\text {aglom }} *\right.$ PPI/100 $)$

Using multiple linear regression method assesses the level of significance of the factors involved, the time factor is not significant for a significance level of $95 \%$. The results adjusted to a multiple linear regression model reveals the average combustion efficiency of sawdust agglomerated material + clay from the description of the relationship between performance and 3 independent variables, the equation of the fitted model is:
Dado que el p-valor en la Tabla ANOVA es inferior a 0.01 , existe relación estadísticamente significativa entre las variables para un nivel de confianza del $99 \%$. El estadístico R-cuadrado indica que el modelo explica aproximadamente un $96 \%$ de la variabilidad en el rendimiento.
Since the p-value in the ANOVA Table is less than 0.01 , statistically significant relationship exists between the variables for a confidence level of $99 \%$. Rsquare statistic indicates that the model explains about $96 \%$ of the variability in performance. 
El valor del aglomerante se introduce en tantos porcentuales y la P en MPa.

La relación funcional explica el proceso donde incrementos del contenido de aglomerante pueden limitar el rendimiento producto de la incombustibilidad del material arcilloso que aglutina la biomasa, lo que puede contribuir a la aparición de materiales no quemados, lo cual muestra una plena correspondencia de los resultados encontrados en este trabajo con la teoría.

No obstante los valores de rendimiento de la combustión obtenidos resultan relativamente altos en el intervalo del $92 \%-98 \%$.

Según Assureira 2002 el rendimiento de la combustión de briquetas fabricadas de paja de arroz obtenidas mediante la aplicación de baja energía de compactación, puede alcanzar valores en el entorno del $98 \%$, valor comparable al resultado que se obtiene en briquetas en el presente trabajo.

Según la literatura consultada (Ortiz, 2005), cuanto más denso es un biocombustible sólido más tarda en arder y por tanto manifiesta el material densificado una relativa disminución de su combustionabilidad.

Esto puede corresponderse a una limitada presencia de oxígeno en poros interconectados en el interior de la biomasa densificada, capaz de intensificar la combustión y por tanto el proceso se desarrolla con mayor dificultad; esta circunstancia podría resultar favorable para productores de cerámica roja, ya que en múltiples ocasiones el combustible tradicional (leña) se volatiza ó consume aceleradamente sin lograr que los hornos se calienten completamente, trayendo consigo la disminución de la productividad y la calidad del producto cerámico.

Eficiencia energética del biocombustible

La eficiencia energética del biocombustible esta' relacionada con diversos factores que repercuten sobre el mejor aprovechamiento del calor generado, por tanto su incremento esta asociada a la disminución de las pérdidas para con ello restringir los índices de consumo especifico y la consecuente mejora ambiental (Rodríguez, 2000).

En el municipio Manicaragua, de la provincia Villa Clara, Cuba, la Cooperativa de Producción Ramón Bernal constituye un importante centro de producción de ladrillos rojos. En el centro se dispone de un horno rustico con capacidad de 3500-4000 ladrillos por quema,
The value of binder is introduced into several percentage and $\mathrm{P}$ in $\mathrm{MPa}$.

The functional relationship explains the process where the binder content increases may limit product performance of the fireproofing material that binds clay biomass, which may contribute to the occurrence of unburned material, which shows a complete correspondence of the results of this work with theory.

However efficiency combustion values obtained are relatively high in the range of $92 \%-98 \%$. According

Assureira 2002, the combustion efficiency of briquettes made of rice straw obtained by applying low compaction energy can reach values at around $98 \%$, which is comparable to the result obtained in briquettes of the present research.

According to the literature (Ortiz, 2005), the denser a solid biofuel longer it takes to burn and therefore the densified material shows a relative decrease in combustion.

This may correspond to a limited presence of oxygen inside the interconnected pores of densified biomass, which can enhance combustion and therefore the whole process is more difficult, this situation could be favorable for the productors of red ceramics, as in repeatedly traditional fuel (wood) is consumed rapidly or volatilized without allowing furnaces to heated sufficiently, declining in productivity and quality of the ceramic product.

Energy efficiency of biofuel

Energy efficiency of biofuels is related to various factors impacting on a better use of the generated heat, therefore its increase is associated with reduced losses to restrict specific consumption rates and the resulting environmental improvement (Rodríguez, 2000).

In Manicaragua municipality, province of Villa Clara, Cuba, Ramon Bernal Production Cooperative is an important center of production of red bricks. The center has a rustic oven capable of burning 3500-4000 bricks, 
el mismo se instrumenta con el equipo analizador de gases de la combustión (RBR-ECOM-SG PLUS), y se comprueba la variación de la temperatura en el tiempo y el contenido de las emisiones gaseosas, mediante un programa experimental donde se controlan las variables temperatura, tiempo de cocción y carga de combustible.

Se materializa la sustitución de la leña por el biocombustible logrando la obtención de curvas temperatura versus tiempo y versus carga para diferentes procesos o quemas, primero con un cien por ciento de leña, se obtiene como criterio comparativo el cálculo teórico del $\mathbf{1 0 0} \%$ de sustitución de la leña por los BSC manteniendo el máximo consumo energético y la máxima disminución de combustible para lograr el $50 \%$ de eficiencia energética, en segundo lugar se realiza la sustitución de la leña en el entorno del $30-50 \%$ de la cantidad inicial pero se mantiene el consumo energético al mismo nivel y finalmente se realiza la disminución del consumo bruto de energía a partir de la disminución del total de combustible.

Se prevé la disminución del consumo energético total, garantizando los niveles de temperatura de forma tal que posibilite la transformación de la arcilla (800 $900{ }^{\circ} \mathrm{C}$ ) a partir de un régimen de carga del combustible a razón de $300 \mathrm{Kg}$. /h.

En la Tabla 1 se muestran las características de diferentes maderas que han sido empleadas para realizar la carga del horno en los experimentos comparativos realizados para este estudio. the same is implemented with the computer analyzer flue gas (RBR-ECOM-SG PLUS), and check temperature variation in timing and content of the gaseous emissions through a pilot program where temperature variables are controlled as well as fire time and fuel load.

Substitution of wood by biofuel is produced in order to obtain temperature versus time curves and versus load for different processes or burning, first with $\mathbf{1 0 0} \%$ of fuelwood. It is obtained as a comparative approach of theoretical calculation of $\mathbf{1 0 0} \%$ replacement of wood by BSC maintaining maximum power consumption and the maximum decrease of fuel to achieve $50 \%$ energy efficiency. In second place it is produced the replacement of wood in around $30-50 \%$ of the initial amount but remains energy consumption at the same level and eventually performs the reduction of gross energy consumption from the decrease in total fuel.

The decrease of total energy consumption is expected, ensuring temperature levels in a manner that enables transformation of clay $\left(800-900{ }^{\circ} \mathrm{C}\right)$ from a fuel loading system at a rate of $300 \mathrm{~kg} / \mathrm{h}$.

Table 1 shows the characteristics of different woods that have been used for charging furnace in the comparative experiments conducted by this study.

Tabla 1. Resultados del análisis inmediato por tipo de madera y para el BSC Table 1. Immediate analysis results by wood type and BSC

\begin{tabular}{|c|c|c|c|c|c|}
\hline $\begin{array}{l}\text { Tipo/elementos en \% } \\
\text { Type/elements \% }\end{array}$ & $\begin{array}{l}\text { Humedad \% } \\
\text { Humidity\% }\end{array}$ & $\begin{array}{l}\text { Carbono fijo \% } \\
\text { Fixed carbon } \%\end{array}$ & $\begin{array}{l}\text { Volátiles \% } \\
\text { Volatile \% }\end{array}$ & $\begin{array}{c}\text { Cenizas } \% \\
\text { Ashes } \%\end{array}$ & $Q^{i} \mathbf{k J} / \mathbf{K g}$. \\
\hline Guásima (Guazuma ulmifolia) & 44.5 & 11.0 & 43.4 & 1.2 & 8.720 \\
\hline Guanina (Senna uniflora) & 37.7 & 10.5 & 51.1 & 0.7 & 9.735 \\
\hline Marabú (Dichrostachys cinerea) & 35.7 & 10.9 & 52.5 & 0.9 & 10.139 \\
\hline BSC & 9.2 & 3.1 & 72.9 & 14.8 & 13.195 \\
\hline
\end{tabular}


La Figura 4 muestra el hogar de fuego del horno experimental, en el que se identifican claramente los BSC y la llama resultante de la combustión de la parte sólida del biocombustible y los elementos volátiles

En la Figura 5 se muestra gráficamente la relación temperatura versus carga de combustible para las diferentes quemas experimentales, así como las mediciones realizadas durante el proceso de quema empleando el bloque sólido. Se estima como las curvas temperatura versus carga del bloque sólido alcanzan valores de pendientes más pronunciadas que en el caso del empleo de la leña, además se aprecia una trascendente diferencia en la combustión al lograr disminuirse el consumo total de combustible en la quema cuando se emplea el bloque sólido combustible.
Figure 4 shows experimental oven, which clearly identifies BSC and the flame from the combustion of the solid biofuel and volatile elements.

Figure 5 shows graphically the relationship of fuel versus temperature for different experimental burns and measurements taken during the burning process using the solid block. It is estimated as temperature curves versus load of solid block which reach values of steeper slopes in the case of the use of wood and also it can be seen an important difference in the combustion to achieve reduction of total fuel consumption in burning when used combustible solid block.

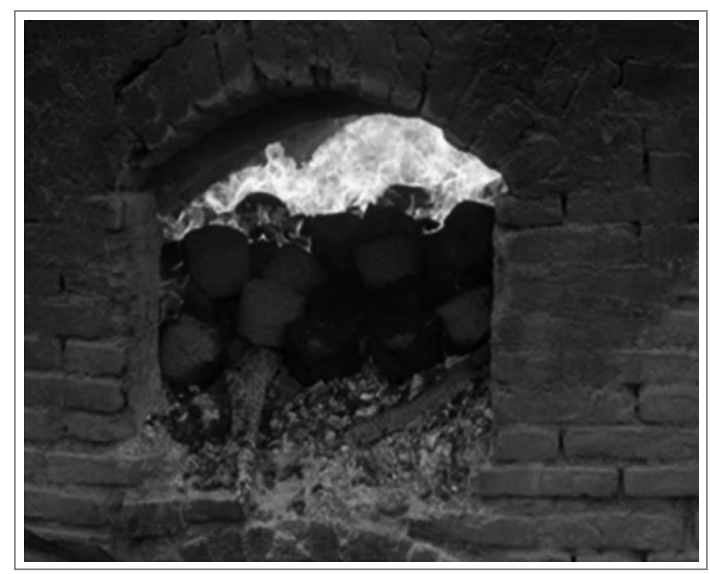

Figura 4. Detalle del hogar de fuego del horno, sustitución de la leña por el biocombustible BSC

Figure 4. Furnace combustion detail, wood substitution by biofuel BSC

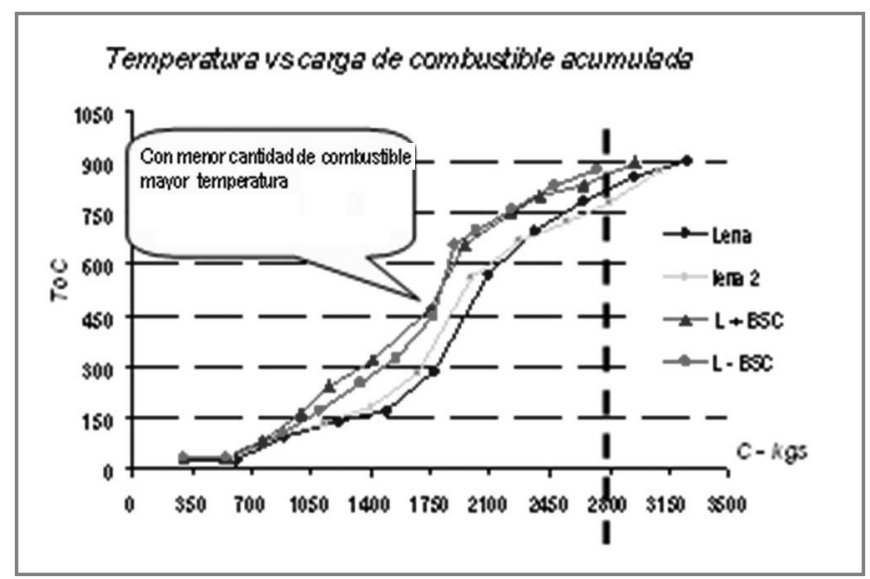

Figura 5. Variación de la temperatura con la carga acumulada

Figure 5. Temperature variation with cumulative load 
De estudios previos realizados a la leña tradicionalmente empleada y al BSC se infiere que el trazado de las curvas puede estar influenciado por el contenido superior de humedad de la leña verde que implica un mayor consumo inicial del calor generado en el horno, de forma tal que se precisa una energía adicional para eliminar esta humedad de la madera o leña, provocando la consecuente disminución de la temperatura de los gases.

Complementariamente esta situación puede estar también relacionada con el mayor volumen de gases generados al ser utilizados los BSC dado probablemente por los productos de las reacciones de los componentes del material arcilloso y por un mayor coeficiente de exceso de aire lo cual mejora el intercambio de calor entre el hogar de fuego y los ladrillos verdes y también por el efecto retardador sobre las reacciones de combustión que produce la densidad del BSC en relación con el contenido de material arcilloso.

Se demuestra según los resultados de las quemas experimentales como es posible disminuir el consumo total de combustible tradicional hasta un $15-20 \%$ en peso del valor promedio actual con la consiguiente mejora de hasta un $40 \%$, en la eficiencia energética del horno manteniendo el valor adecuado de la temperatura para que el proceso se desarrolle satisfactoriamente sin ejecutar modificaciones importantes a la tecnología existente.

La sustitución de leña por el biocombustible densificado superior a un $50 \%$ del peso total del combustible, puede no resultar práctico en las condiciones de hornos tradicionales, donde la periódica acumulación de cenizas y su consiguiente evacuación de las parrillas comienza a ser una problemática para el proceso de operación.

Según Mason, (2002,) el mejor valor de eficiencia energética reportado para estas tecnologías del ladrillo rojo cerámico alcanza el $\mathbf{5 0} \%$ sin embargo es posible analizar diversas vías para disminuir las pérdidas que se producen por incombustión química, incombustión mecánica y otras. La mejora del aislamiento térmico de paredes, reinyectar los gases calientes y mejorar la relación aire combustible pueden acrecentar la eficiencia del proceso.

Con el empleo de la alternativa energética propuesta es posible en promedio aumentar la relación ladrillos / Kg. de combustible desde 1.1 a 1.4, esto se debe a que el calor necesario para secar el combustible es menor que cuando se emplea solamente leña,
In previous studies of the wood traditionally used and the BSC it is inferred that the contours can be influenced by higher moisture content of green wood which implies a higher initial consumption of heat in the oven, so that additional energy required to remove the moisture of wood causing a concomitant decrease in the temperature of gases.

Additionally this may also be related to the increased volume of gases to be used by the BSC as probably the products of the reactions of the components of the clay material and a higher coefficient of excess air, which improves the heat exchange between fire and the green bricks as well as the retarding effect on the combustion reactions that produces the density of BSC in connection with the content of clay material.

It is shown by the results of experimental burns as possible to reduce the total consumption of traditional fuel to a $15-20 \%$ by weight of the current average value with the consequent improvement of up to $40 \%$ in the energy efficiency of the furnace to maintain the value proper temperature for the process to develop successfully without major modifications to existing technology.

Replacement of wood by densified biofuel superior than $50 \%$ of the total weight of the fuel may not be practical in terms of traditional kilns, where periodic accumulation of ashes and its subsequent evacuation is becoming a problem for the operational process.

According to Mason (2002,) the best value in energy efficiency reported for these red brick ceramic technology reach $\mathbf{5 0} \%$ but it is possible to analyze different ways to reduce losses caused by chemical lack of combustion, mechanics and other. Improving thermal insulation of walls, re-inject hot gases and improve airfuel ratio can increase the efficiency of the process.

With the use of proposal alternative energy may increase the ratio on average bricks / $\mathrm{kg}$ of fuel from 1.1 to 1.4 , this is because the heat needed to dry the fuel is lower than when using only wood, 
acrecentando en consecuencia la cantidad relativa de energía directamente utilizada en el proceso de transformación de los ladrillos, relacionado además con el efecto retardador que produce el material arcilloso durante la combustión al disminuir la velocidad de reacción del biocombustible.

En cambio la mayor velocidad con que libera la energía calorífica la leña, hace que esta no sea íntegramente aprovechada en el horno, pues el coeficiente de absorción del calor del ladrillo establece límites en su difusión a través de su masa volumétrica, de igual modo el mayor volumen de gases generado durante la combustión del BSC puede producir un mejor intercambio de calor en toda la columna del horno, lo que puede disminuir la falta de isotermia característica de este tipo de instalación.

En las quemas se realizan ensayos físicomecánicos de campo al ladrillo fabricado (resistencia y sonido), así como el control visual al $\mathbf{1 0 0} \%$ de ladrillos correspondientes a cada quema, no existiendo ladrillos sobre quemados, al observarse que los ladrillos tienen un color rojo marrón indicación de una adecuada quema, sin agrietamientos ni deformaciones, de igual forma los ensayos de laboratorio concluidos demuestran no existir afectaciones a la calidad del ladrillo por el cambio de la fuente energética.

Al generar la nueva fuente de calor un nivel superior de cenizas al que produce el combustible tradicional, se exige remover con mayor frecuencia los residuos en el interior de la cámara de combustión, por lo que se recomienda adecuar el diseño de las parrillas del horno para mejorar su capacidad de evacuación de las cenizas del bloque sólido, este principio unido al calentamiento inicial necesario del horno son los aspectos más cardinales que limitan en la práctica diaria el empleo de una cantidad intensiva y relativamente mayor. del BSC.

El aumento de la eficiencia energética en la producción de ladrillos de barro cocido y otros productos cerámicos, puede contribuir a disminuir la tala de bosques y potenciar el reciclaje de desechos maderables con relevantes ventajas desde el punto de vista ecológico que estas acciones en el sector de la obtención de los materiales de construcción pueden representar. increasing accordingly the relative amount of energy used directly in the process of transforming bricks, also related to the retarding effect produced by the clay material during combustion by lowering the reaction rate of fuel.

Instead the greater speed with which releases heat energy the wood, makes it not fully exploited in the oven, since the coefficient of heat absorption of the brick sets limits on dissemination through its density, just as the greater volume of gases generated during combustion of the BSC can produce a better exchange of heat throughout the column of the oven, which can reduce the lack of isothermal characteristic of this type of installation.

At burnings physical-mechanical field tests are done to the bricks produced (resistance and sound) and visual inspection of $\mathbf{1 0 0} \%$ for each burning of bricks, with no burnt bricks, the bricks have a red brown colour which indicates proper burning without cracking or deformation. Similarly concluded laboratory tests show there are no effects on the quality of the brick by changing the energy source.

When generating the new heat source a higher level of ashes produced by the traditional fuel requires to remove debris more frequently inside the combustion chamber, so it is recommended to adapt the design of the oven racks to improve their ability to escape from the ashes of the solid block, this principle together with the initial heating of the oven are needed in daily practice for the use of an intensive and relatively higher amount of BSC.

Increasing energy efficiency in production of clay bricks and other ceramic products, can help reduce logging and increase the recycling of waste timber with relevant advantages from the ecological point of view that these actions for obtaining building materials can represent. 


\section{Conclusiones}

El proceso tecnológico propuesto confirma la obtención de un material compuesto biocombustible, basado en una mezcla densificada de suelo arcilloso y residuos lignocelulósicos maderables, facilitando su manejo adecuado. La densidad del bloque sólido tiende a aumentar con la actividad y el contenido de aglomerante, que a su vez influye en la razón de combustión al disminuir la velocidad de reacción del biocombustible, cooperando en la mejora de la eficiencia del proceso de cocción del ladrillo de barro, al disminuir el consumo especifico de combustible con respecto a la madera ó leña como fuente energética tradicional.

\section{Agradecimientos}

Los autores desean agradecer a las siguientes instituciones por su apoyo en el desarrollo de este trabajo: CITMA Ministerio de Ciencia, tecnología y medio ambiente de Cuba, UNIOVI Universidad de Oviedo.

\section{Conclusions}

The proposed technological process confirms obtention of a composite biofuel material, based on a mixture of clay soil densified cellulosic waste timber which facilitates an appropriate management. Density of the solid block tends to increase with activity and content of binder, which in turn influences combustion rate of the slow reaction of biofuel, cooperating in improving the efficiency of the cooking process brick mud to reduce specific fuel consumption compared to wood or wood as traditional energy source.

\section{Acknowledgements}

Authors greatly acknowledge the following institutions for their support to this study: CITMA, ministry of science, technology and environment of Cuba, UNIOVI Universidad de Oviedo.

\section{Referencias / References}

Assureira E. (2002), Combustible alternativo la cascarilla de arroz Palestra Portal de asuntos públicos de PUCP http://palestra.pucp.edu.pe Betancourt D. Martirena, F. Day R. Díaz Y. (2007), "Influencia de la adición de carbonato de calcio en la eficiencia energética de la producción de ladrillos de cerámica roja Revista Ingenieria de Construcciones Vol. 22, No 3 Diciembre.

Bhattacharya S.C. (2002), Biomass Energy Use and Densification in Developing Countries. Abstract of the first world conference on pellets, Stockholm, 2-4 September 2002.

Chin O. C. y Siddiqui K. M. (2000), Characteristics of some biomass briquettes prepared under modest die pressure. Bimass and Bioenergy, (2000). 18. 223-228.

Christofer R., Marcus O., Rolf Grez and et all (2007), Effect of raw material composition in woody biomass pellets on combustion characteristics Biomass and Bioenergy 31 (2007) 66-72

Curbelo A. García B. (2006), Contribución de la biomasa no cañera a la generación de electricidad en Cuba. / División de Industria y Energía, Agencia de Ciencia y Tecnología, Cuba. (http://www.fao.org/docrep/T2363s0h.htm\#TopOfPage) (última visita: Septiembre).

Cukierman A. L., Della Rocca P. A., Bonelli P. R. y Cassanello M. C. (1996), On the Study of Thermo chemical Biomass Conversion. Trends in Chemical Engineering, 3, 129-144.

Dopico Montes de Oca, J.J. Martirena, F. Day R.L. (2008), Desarrollo de hormigones con aglomerante Cal - puzolana fina como material cementicio suplementario. Revista Ingenieria de Construcciones Vol 23 Diciembre. www.ing.puc.cl/ric

González M. L. (2004), "Estudio comparativo de BSC y Maderas en la obtención de eco-materiales" Universidad Central "Marta Abreu" de Las Villas Facultad de Ingeniería Mecánica Departamento: Energía; TD.Tutor: Machado I. Moya, H.I.

Gonzáles R. (2003), Densificación de Biomasa para la obtención de Energía y Materiales de Construcción TGC.. Santa Clara Departamento de Ingeniería Civil T: Martirena F.

Guerra Caridad W. Menéndez E. A y colab. “Estadística” (2006), Editorial Félix Varela, La Habana.

Faxälv O. y Nyström O. (2007), Biomass Briquettes in Malawi Degree Project Department of Management and Engineering ISSN 1400-3562.

Jamradloedluk J., Panomai C. and et all (2005), Physical properties and combustion performance of briquettes produced from two pairs of biomass species Faculty of Engineering, Thailand.

Machado I, Martirena, F. y col. Obtención de biomasa densificada con baja energía de compactación (2002), CD Memorias 5 TO Simposio Internacional de Estructuras y Materiales de Construcción. Santa Clara

Martirena F. , Machado I. y Seijo P. (2003), Waste to energy technologies targeting the poor. The Cuba case study. Full Proceedings World Renewable Energy Congress Published by Pergamon Press, Elsevier Ltd.

Mason K. (2002), "Ten rules for energy efficient, cost effective brick firing." BASIN, Building Advisory, United Kingdom.

Ortíz L., Tejada A. y Vazquez A. (2005), Aprovechamiento de la Biomasa Forestal producida por la Cadena Monte-Industria. Parte III: Producción de elementos densificados, Revista CIS-Madera.

Pulido A. (2005), Modelos Econométricos. Editorial Félix Varela La Habana. 